\title{
Response of Sorghum vulgare L. Cultivars to Gamma Irradiation, a Preliminary Approach
}

\author{
Ishtiaq Ahmad ${ }^{1 *}$, Izhar Ahmad ${ }^{1}$, Zahir Muhammad ${ }^{2}$ and Barkat Ullah ${ }^{1}$ \\ ${ }^{1}$ Department of Botany, Islamia College Peshawar, Pakistan. \\ ${ }^{2}$ Department of Botany, University of Peshawar, Pakistan. \\ *Corresponding Author: phytology2025@gmail.com
}

Article Received 14-06-2021, Article Revised 03-07-2021, Article Accepted 01-11-2021

\begin{abstract}
The seeds of four Sorghum vulgare L. cultivars (Asian, Indian, Mycho, Summer graze) exposed to various doses of gamma irradiation ( $15 \mathrm{krad}, 20 \mathrm{krad}, 25 \mathrm{krad}, 30 \mathrm{krad})$ were critically examined for percent emergence, plumule and radical growth, fresh and dry weight and moisture contents. Irradiation doses were instrumental in creating significant variability for all traits except percent emergence, indicating that Sorghum vulgare L. cultivars did not perform uniformly across different gamma rays treatments. The cultivars varied significantly $(\mathrm{P}<0.05)$ for all characters. Similarly, doses $x$ cultivars effects were highly significant for radical growth, percent emergence, biomass as well as moisture contents, indicating greater instability of performance for mentioned characters across different irradiation treatments. Mutagenic treatments shifted mean values towards negative direction for almost all traits except moisture contents. Mutagenic effectiveness was found to be dependent upon dose and cultivars concerned. The present study categorically showed that the applied doses of gamma irradiation were unable to enhance percent emergence and seedling growth. Inter cultivar genetic variations were observed among the cultivars.
\end{abstract}

Key words: gamma rays, sorghum cultivars, mutation breeding.

\section{Introduction}

Mutation breeding is the process of exposing seeds to chemicals or radiation in order to generate mutants with desirable traits to be bred with other cultivars. Plants created using mutagenesis are sometimes called mutagenic plants or mutagenic seeds. From 1930-2004 more than 2250 mutagenic plant varieties have been released that have been derived either as direct mutants $(70 \%)$ or from their progenies (30\%). Crop plants account for $75 \%$ of released mutagenic species with the remaining $25 \%$ ornamentals or decorative plants (Ahloowalia et al., 2004). However, it is unclear how many of these varieties are currently used in agricultural production around the world, as these seeds are not always identified or labeled as being mutagenic or having a mutagenic provenance. There are different kinds of mutagenic breeding such as using chemical mutagens like ethyl methane sulfonate (EMS) and dimethyl sulfide, radiation and transposons are used to generate mutants. Mutation breeding is a very effective technique to produce traits in crops such as larger seeds, new colors or sweeter fruits that either cannot be found in nature or have been lost during evolution. The biological effect of gamma-rays is based on the interaction with atoms or molecules in the cell, particularly water, to produce free radicals which can damage different important compounds of plant cells. However, gamma rays accelerate the softening of fruits, causing the breakdown of middle lamella in cell wall (Tarroum et al., 2011). They also influence the plastid development and their function such as starch-sugar inter-conversion. Although, gamma radiation is a mutational tool with diverse applications in agriculture, industry and medicine, its potential exploitation in agriculture is limited mainly because of lack of information awareness on optimal dose of irradiation which differs from one crop to another crop and from one application to another application. Radiation mediated morphological, structural and/or functional changes in a plant are governed by the intensity and duration of the gamma irradiation (Tarroum et al., 2011). Sorghum vulgare L. is an important crop being cultivated for grain and fodder production. Sorghum cultivation in Pakistan is facing constraints that are limiting its expansion in terms of area and sustainable stable yield. High concentration of cattle in the country resulting in high demand for seed concentrate necessitates that new adaptable varieties of sorghum are developed for wider cultivation (Larik et al., 2009). Many workers had studied the effects of gamma rays on various plants (Moussa 2011; Sherif et al., 2011; Tarroum et al., 2011; Marcu et al., 2013; Maamoun et al., 2014; Santosa et al., 2014; Zanzibar \& Sudraja, 2016). Doses of gamma irradiation positively affected growth and seed yield of Abelmoschus esculentus L. (Hegazi and Hamideldin, 2010). Dubey et al. (2007) reported increase in plant height and branches per plant of Abelmoschus esculentusL L. irradiated by different doses of gamma rays. It has been indicated that the effect of interaction between doses of gamma rays and okra genotypes was highly significant in the number of pods per plant and seeds per pod (Ullah, 2014). The present study was designed to compare relative effectiveness of gamma rays for inducing improvement in primary attributes of Sorghum vulgare L. cultivars having different histories of selection. The study provides a guideline for other workers in selection of appropriate doses of gamma irradiation for testing in field conditions.

\section{Materials and Method}

Seeds of Sorghum vulgare L. cultivars (Asian, Indian, Mycho and Summer graze) were obtained from open market (chowk e yadgar, Peshawar). Cobalt 60 source was 
used to treat sorghum seeds at the Radiation Technology Department, Nuclear Institute for Agriculture (NIFA), Peshawar, Pakistan. The radiator carried plaque source rack $\left(1 \times 1 \mathrm{~m}^{2}\right)$ containing $\mathrm{CoS} 43 \mathrm{HH}$ source types from the rest position to the irradiation position in the irradiation chamber and a transport system for rotating the tote boxes to ensure a dose uniformity ratio of approximately unity. The seeds of sorghum cultivars were subjected to 15,20 , 25 and 30 krads doses of gamma irradiation. Four (4) samples of dry sorghum cultivars seeds each treated at a position of $71 \mathrm{~cm}$ from the floor and $110 \mathrm{~cm}$ from the gamma irradiation source in the irradiation chamber. A dosimeter was attached to each sorghum sample subjected to gamma irradiation. Seeds viability was checked prior gamma irradiation treatment by putting some seeds in a petri dish with filter paper soaked with water. Non radiated seeds were used as control. The glass ware were properly washed and sterilized at $65^{\circ} \mathrm{C}$ for 24 hours in the oven prior to starting the experiment. Seeds were placed equidistantly on two folded whatman filter paper as seed bed in petri dishes of equal sizes. Each treatment was replicated five times with 100 seeds in each replicate. Equal volume of tape water was added to all petri dishes. The petri dishes were incubated at $25^{\circ} \mathrm{C}$ for 72 hours, data for germination percentage $(\%)$, plumule, radical growth $(\mathrm{cm})$ and fresh weight was collected. Dry weight (gm) and moisture contents (\%) were determined after the seedlings were dried in the oven at $65{ }^{\circ} \mathrm{C}$ for 72 hours following (Hussain, 1989). Fisher analysis of variance technique and LSD test at $0.05 \%$ probability was applied on the data to compare the differences among doses, cultivars and their interactions (Steel \& Torrie, 1984).

\section{Results and Discussion}

Effects on plumule growth $(\mathbf{c m})$ : The gamma radiation doses and sorghum cultivars induced significant $(\mathrm{p}<0.05 \%)$ variations in plumule growth. However, the effect of doses $\times$ cultivars on plumule growth was highly non-significant (Table 1).

Table 1. Mean-square values and significance tests for plumule and radicle growth, germination \%, fresh and dry weight and moisture contents of four Sorghum vulgare L. cultivars evaluated with variable doses of gamma radiation.

\begin{tabular}{|l|l|l|l|l|l|l|l|}
\hline Source & D.F. & $\begin{array}{l}\text { Plumule } \\
\text { Growth }\end{array}$ & $\begin{array}{l}\text { Radicle } \\
\text { Growth }\end{array}$ & $\begin{array}{l}\text { Germination } \\
\text { Percentage }\end{array}$ & $\begin{array}{l}\text { Fresh } \\
\text { Weight }\end{array}$ & $\begin{array}{l}\text { Dry } \\
\text { Weight }\end{array}$ & $\begin{array}{l}\text { Moisture } \\
\text { Contents }\end{array}$ \\
\hline Doses (D) & 4 & $0.0000^{\mathrm{S}}$ & $0.0000^{\mathrm{S}}$ & $* * * * * *$ & $0.0000^{\mathrm{S}}$ & $0.0000^{\mathrm{S}}$ & $0.0002^{\mathrm{S}}$ \\
\hline Cultivars (C) & 4 & $0.0105^{\mathrm{S}}$ & $0.0000^{\mathrm{S}}$ & $0.0000^{\mathrm{S}}$ & $0.0000^{\mathrm{S}}$ & $0.0000^{\mathrm{S}}$ & $0.0003^{\mathrm{S}}$ \\
\hline $\mathrm{D} \times \mathrm{C}$ & 3 & $0.1055^{\mathrm{SS}}$ & $0.0116^{\mathrm{S}}$ & $0.0002^{\mathrm{S}}$ & $0.0000^{\mathrm{S}}$ & $0.0000^{\mathrm{S}}$ & $0.0010^{\mathrm{S}}$ \\
\hline Error & 12 & & & & & & \\
\hline Total & 76 & & & & & & \\
\hline
\end{tabular}

$\mathrm{S}=$ Significant NS = Non Significant D.F. $=$ Degree of Freedom

The control seeds recorded the highest plumule growth value $(5.69 \mathrm{~cm})$ followed by a dose of $15 \mathrm{krad}(3.33)$ gamma irradiation (Table 2). Moreover, variations between control and applied doses were highly significant $(\mathrm{p}<0.05 \%)$. However, plumule growth values recorded from $20 \mathrm{krad}, 25 \mathrm{krad}$ and $30 \mathrm{krad}$ were highly nonsignificant among each other. Among treatments, the dose of $20 \mathrm{krad}$ caused maximum inhibition of plumule growth $(0.94 \mathrm{~cm})$ (Table 2; Fig. 1). The cultivar Mycho showed the highest plumule growth value $(2.96 \mathrm{~cm})$. The same cultivar (Myco) showed the significant variations with genotypes Asian and Indian for subject parameter. However, the cultivars Myco and Summer graze exhibited a nonsignificant variation upon comparing (Fig. 4; Table 2).

Growth inhibition induced through gamma irradiation may be attributed to cell cycle arrest in the G2/M phase during somatic cell division and/or to a variety of damages in the entire genome (Preuss \& Britt,
2003). Processes like auxin destruction, changes of the ascorbic acid contents and physiological and biochemical disturbances could induce the inhibition of plant germination and development (Shah et al., 2008). Chaudhuri (2002) reported that when radiation is sufficient to reduce the rooting percentage, the root lengths do not exceed a few millimeters in length. Due to metabolic disorders in the seeds after gamma irradiation, the seeds are unable to germinate or to survive more than a few days. Plant survival to maturity depends on the nature and extent of chromosomal damage. The frequency of chromosomal damage with increasing dosage may be responsible for reduction in plant development (Kiong et al., 2008). The present study agree to the observed reduction in shoot length in plants raised from gamma irradiated seeds by various workers (Shah et al., 2008; Borzouei et al., 2010; Kabori et al., 2010; Tabassum et al., 2011; Peykarestan \& Seify, 2012). 


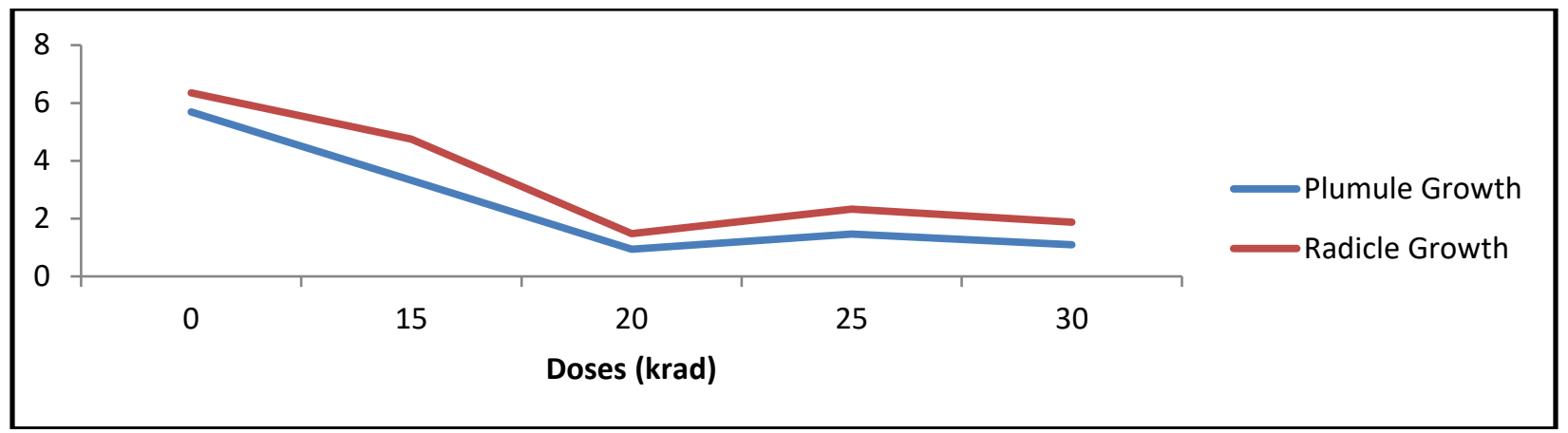

Fig 1. Effect of gamma irradiation on plumule and radical growth of Sorghum vulgare $\mathrm{L}$.

Table 2. Effect of gamma irradiation (krad) on plumule growth $(\mathrm{cm})$ of Sorghum vulgare L. cultivars.

\begin{tabular}{|l|l|l|l|l|l|}
\hline Doses (krad) & Asian & Indian & Mycho & Summer graze & Doses Means \\
\hline Control & 5.63 & 3.93 & 6.35 & 6.85 & $5.69^{\mathbf{a}}$ \\
\hline 15 & 3.08 & 3.08 & 4.30 & 2.87 & $3.33^{\mathbf{b}}$ \\
\hline 20 & 0.45 & 1.00 & 1.13 & 1.17 & $0.94^{\mathbf{c}}$ \\
\hline 25 & 1.16 & 1.36 & 1.64 & 1.69 & $1.46^{\mathbf{c}}$ \\
\hline 30 & 0.71 & 1.09 & 1.38 & 1.20 & $1.09^{\mathbf{c}}$ \\
\hline Cultivars Means & $2.21^{\mathbf{b c}}$ & $2.09^{\mathbf{c}}$ & $2.96^{\mathbf{a}}$ & $2.76^{\mathbf{a b}}$ & \\
\hline
\end{tabular}

Lsd value at $0.05 \%$ level of significance for Doses $=0.6621$ and Cultivars $=0.5922$. Values bearing similar letters in rows and columns are statistically non-significant at $0.05 \%$ level of significance.

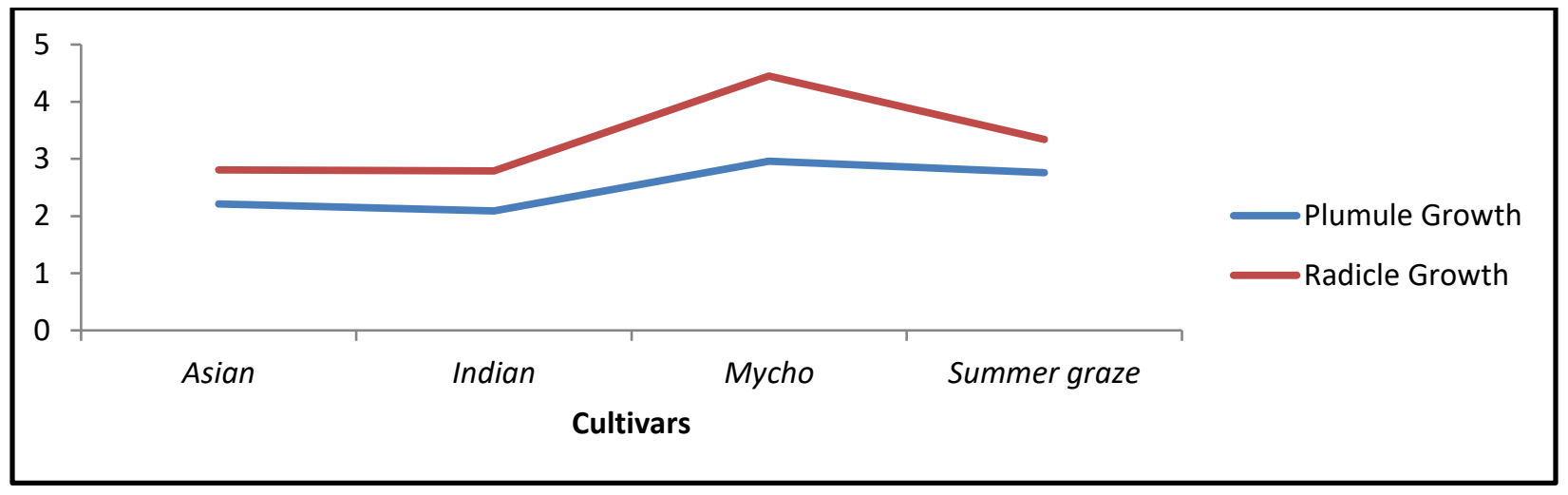

Fig 4. The varietal differences among selected Sorghum vulgare L. cultivars in terms of plumule and radical growth (cm).

Effect of various gamma irradiations on radical growth $(\mathbf{c m})$ of sorghum cultivars: Radical growth exhibited significant variations $(\mathrm{p}<0.05 \%)$ for doses, cultivar and their interaction (doses $\times$ cultivars) (Table 1 ).

The non-irradiated (control) seeds recorded maximum $(6.35 \mathrm{~cm})$ radical growth (Table 3). Furthermore, variations between control and irradiation doses were highly significant $(\mathrm{p}<0.05 \%)$. Among treatments, $20 \mathrm{krad}$ irradiation dose recorded the lowest radical growth value (1.48) as affected by various gamma irradiations. The cultivar Mycho showed highest radical growth value $(4.45 \mathrm{~cm})$ exhibiting highly significant variations when compared with genotypes Summer graze $(3.34 \mathrm{~cm})$, Asian $(2.81 \mathrm{~cm})$ and Indian $(2.79 \mathrm{~cm})$ respectively. However, variations among cultivars Asian, Indian and Summer graze were found as non-significant (Table 3; Fig. 4). The study related to interaction (doses $x$ cultivars) showed that a dose of $20 \mathrm{krad}$ is inhibitory for radical growth of the selected cultivars. On the contrary, zero gamma treatment is stimulatory for the studied genotypes (Table 3).

The recorded data clearly showed the injurious nature of the applied gamma irradiation doses (Fig. 1). The reduction in radical growth may be attributed to the altered physiology of the embryo by gamma rays or may be meristematic cells damaged by the irradiation doses resulting in reduced radical activity. Among the cultivars, increased radical growth of Mycho shows its comparative 
resistivity to gamma irradiation. Gamma irradiation was reported to induce oxidative stress with over production of reactive oxygen species such as superoxide radicals, hydroxyl radicals and hydrogen peroxides which react rapidly with almost all structural and functional organic molecules including proteins, lipids and nucleic acids causing disturbance of cellular metabolism (Al-Rumaih \& Al-Rumaih, 2008). Reactive oxygen species can react with nearly all cell constituents. And due to lipid peroxidation, the membrane loses its stability and its permeability is enhanced leading to damages of the cell structure and disturbances of normal physiological functions (Moghaddam et al., 2011). Massive doses of ionizing radiation have been shown to induce physiological changes in plants such as enhancement of respiration, increase in ethylene production and induction of enzyme activities (particularly for phenolic metabolisms and accumulation of specific protein species). These effects are considered a consequence of both the direct interactions between the ionizing radiation and the macromolecular structures and the indirect action of ROS generated by water radiolysis (Marcu et al., 2013) preventing plants from normal growth. The present observations are parallel to the findings of Cheema \& Atta, (2003), Borzouei et al. (2010) and Peykarestan \& Seify, (2012) who reported reduction in radicle or root length in rice, wheat and redbean, respectively raised from gamma irradiated seeds.

Table 3. Effect of gamma irradiation (krad) on radical growth (cm) of Sorghum vulgare L. cultivars.

\begin{tabular}{|c|c|c|c|c|c|}
\hline Doses (krad) & Asian & Indian & Mycho & Summer graze & Doses Means \\
\hline Control & $5.76^{\mathrm{bc}}$ & $4.54^{\text {cde }}$ & $7.59^{\mathrm{a}}$ & $7.51^{\mathrm{a}}$ & $6.35^{\mathrm{a}}$ \\
\hline 15 & $4.87^{\mathrm{cd}}$ & $3.77^{\text {def }}$ & $7.02^{\mathrm{ab}}$ & $3.32^{\mathrm{d}-\mathrm{g}}$ & $4.75^{b}$ \\
\hline 20 & $0.92^{\mathbf{j}}$ & $1.57^{\mathrm{ij}}$ & $1.55^{\mathrm{ij}}$ & $1.88^{\mathrm{g}-\mathrm{j}}$ & $1.48^{\mathrm{d}}$ \\
\hline 25 & $1.29^{\mathrm{j}}$ & $2.49^{\mathrm{f}-\mathrm{j}}$ & $3.22^{\mathrm{e}-\mathrm{h}}$ & $2.32^{\mathrm{f}-\mathrm{j}}$ & $2.33^{c}$ \\
\hline 30 & $1.20^{\mathbf{j}}$ & $1.57^{\mathrm{ij}}$ & $3.04^{\mathrm{e}-\mathrm{i}}$ & $1.67^{\text {hij }}$ & $1.87^{\mathrm{cd}}$ \\
\hline Cultivars Means & $2.81^{\mathbf{b}}$ & $2.79^{b}$ & $4.45^{\mathrm{a}}$ & $3.34^{\mathbf{b}}$ & \\
\hline
\end{tabular}

Lsd value at $0.05 \%$ level of significance for Doses $=0.8139$, Cultivars $=0.7280$ and Doses $\mathrm{x}$ Cultivars interaction $=$ 1.628. Values bearing similar letters in rows and columns are statistically non-significant at $0.05 \%$ level of significance.

Impact of gamma irradiations on percent $(\%)$ emergence of various sorghum cultivars: Germination percentage confirmed significant $(\mathrm{p}<0.05 \%)$ interaction effects between doses and cultivars. In similar way, selected genotypes recorded significant variations $(\mathrm{p}<0.05 \%)$ for the subject parameter. However, variations among gamma irradiation doses were non-significant (Table 1).

Seeds germination test declared Mycho as an efficient germinating cultivar (84.80) as compared to Asian (76.00), Indian (71.20) and Summer graze (58.80) (Table 4; Fig. 6). The percent emergence value of cultivar Myco varied significantly in contrast to other genotypes. The doses $\times$ cultivars effects on percent emergence were highly significant and inconsistent. Genotypes like Asian, Indian and Mycho showed marked increase in percent emergence over control under a dose of $25 \mathrm{krad}$. Whereas for cultivar Summer graze, the same dose (25 Krad) brought marked reduction in percent emergence compared to zero treatment.
It has been reported that gamma rays can affect seed germination, morphology, anatomy, and physicochemical characteristics of plants, depending on irradiation level (Maamoun et al., 2014). The inhibitory nature of gamma rays is confirmed by many authors while studying on maize, sorghum, abelmoschus, pinus and cicer plants (Irfaq \& Nawab, 2001; Kumar \& Mishra 2004; Thapa, 2004; Khan et al., 2005; Larik et al., 2009; Marcu et al., 2013; Ambavane et al., 2015; Wanga et al., 2020). On the contrary, improvement in seed germination by gamma radiation was also observed in plants like Tectona grandis, Acacia leucophloea, Albizia lebbeck, Ziziphus mauritiana, Pterocarpus santalinus and Terminalia arjuna (Selvaraju \& Raja, 2001; Akshatha \& Chandrashekar, 2013; Akshatha et al., 2013; Zanzibar \& Sudrajat, 2016). In the present study we have obtained non-significant results of gamma rays on germination of sorghum cultivars (Fig. 3). Non-significant effect of doses on germination showed greater stability of sorghum cultivars towards gamma irradiation.

Table 4. Effect of gamma irradiation (krad) on germination percentage (\%) of Sorghum vulgare L. cultivars.

\begin{tabular}{|c|c|c|c|c|c|}
\hline Doses (krad) & Asian & Indian & Mycho & Summer graze & Doses means \\
\hline Control & $66.00^{\text {e-f }}$ & $72.00^{\mathbf{c}-\mathbf{g}}$ & $86.00^{\text {abc }}$ & $66.00^{\text {e-h }}$ & 72.50 \\
\hline 15 & $78.00^{\text {a-f }}$ & $60.00^{\text {gh }}$ & $84.00^{\text {abc }}$ & $68.00^{\text {d-h }}$ & 72.50 \\
\hline 20 & $82.00^{\text {a-d }}$ & $64.00^{\text {fgh }}$ & $80.00^{\text {a-e }}$ & $64.00^{\text {fgh }}$ & 72.50 \\
\hline 25 & $90.00^{\text {ab }}$ & $84.00^{\text {abc }}$ & $92.00^{\mathbf{a}}$ & $40.00^{\mathbf{i}}$ & 76.50 \\
\hline 30 & $64.00^{\text {fgh }}$ & $76.00^{\mathbf{b - f}}$ & $82.00^{\text {a-d }}$ & $56.00^{\mathbf{h}}$ & 69.50 \\
\hline Cultivars means & $76.00^{\mathbf{b}}$ & $71.20^{\mathbf{b}}$ & $84.80^{\mathbf{a}}$ & $58.80^{\mathbf{c}}$ & \\
\hline
\end{tabular}


Lsd value at $0.05 \%$ level of significance for Cultivars $=6.964$ and Doses $\mathrm{x}$ Cultivars interaction $=15.57$. Values bearing similar letters in rows and columns are statistically non-significant at $0.05 \%$ level of significance.

Influence of gamma irradiations on fresh weight (gram) of Sorghum vulgare L: The influence of doses, cultivars and doses $\times$ cultivars was highly significant $(\mathrm{p}<0.05 \%)$ on fresh weight (Table 1$)$.

Plants grown from non-irradiated plants showed significant increase in fresh weight (0.61). However, among the applied doses, some are stimulatory while others are inhibitory for fresh weight. Dose of $20 \mathrm{krad}$ of gamma irradiation caused maximum reduction in fresh weight $(0.25 \mathrm{~g})$ as compared to other treatments (Table 5; Fig. 2). The comparison of values regarding fresh weight confirmed non-significant variations between cultivars Mycho $(0.51 \mathrm{~g})$ and Asian $(0.44 \mathrm{~g})$. In similar way, nonsignificant changes between Indian and Summer graze showed same tendencies of both cultivars towards gamma rays (Table 5; Fig. 5). The effect of interaction between doses and cultivars showed significant inconsistent variations for fresh weight. Plants rose from nonirradiated seeds of cultivars Mycho, Indian and Summer graze showed maximum fresh weight value as compared to other gamma irradiation doses. On the contrary, dose of $15 \mathrm{krad}$ was found stimulatory for cultivar Asian (Table $5)$.

In certain plants, gamma irradiation had negative and hazardous effects on morphology and growth compared to control (Sarduie-Nasab et al. 2010; Hanafy \& Akladious, 2018). Preussa \& Britta (2003) stated that the gamma radiations contribute in cell cycle arrest during cell division that caused decrease in growth rate resulting in lower fresh weight. The reduction in fresh weight seedlings might be attributed to the decrease in seedling growth due to radiation stress (Hanafy \& Akladious, 2018). The reported enhanced shoot fresh weight (ElSherif et al., 2011; Latif et al., 2011; Tabasum et al., 2011) due to gamma irradiation in different plants negates the present findings. However, decreased fresh weight of plants under gamma irradiation (Vanhoudt et al., 2010; Peykarestan \& Seify, 2012) have also been reported which confirmed the present work.

Table 5. Effect of gamma irradiation (krad) on fresh weight (g) of four Sorghum vulgare L. cultivars.

\begin{tabular}{|l|l|l|l|l|l|}
\hline Doses (krad) & Asian & Indian & Mycho & Summer graze & Doses means \\
\hline Control & $0.51^{\text {cde }}$ & $0.47^{\text {def }}$ & $0.78^{\mathrm{a}}$ & $0.67^{\text {abc }}$ & $0.61^{\mathrm{a}}$ \\
\hline 15 & $0.53^{\text {bcd }}$ & $0.33^{\text {f-i }}$ & $0.52^{\text {cde }}$ & $0.38^{\text {d-h }}$ & $0.44^{\mathbf{b}}$ \\
\hline 20 & $0.38^{\mathrm{d}-\mathrm{h}}$ & $0.27^{\mathrm{g}-\mathrm{j}}$ & $0.12^{\mathrm{j}}$ & $0.24^{\text {hij }}$ & $0.25^{\mathrm{d}}$ \\
\hline 25 & $0.36^{\mathrm{e}-\mathrm{i}}$ & $0.38^{\mathrm{d}-\mathrm{h}}$ & $0.70^{\mathrm{ab}}$ & $0.19^{\mathrm{ij}}$ & $0.41^{\mathrm{bc}}$ \\
\hline 30 & $0.42^{\mathrm{d}-\mathrm{g}}$ & $0.29^{\mathrm{ghi}}$ & $0.42^{\mathrm{d}-\mathrm{g}}$ & $0.19^{\mathrm{ij}}$ & $0.33^{\mathrm{cd}}$ \\
\hline Cultivars means & $0.44^{\mathrm{a}}$ & $0.35^{\mathrm{b}}$ & $0.51^{\mathrm{a}}$ & $0.33^{\mathrm{b}}$ & \\
\hline
\end{tabular}

Lsd value at $0.05 \%$ level of significance for Doses $=0.08450$, Cultivars $=0.0558$ and Doses $\mathrm{x}$ Cultivars interaction $=$ 0.1690 . Values bearing similar letters in rows and columns are statistically non-significant at $0.05 \%$ level of significance.

Dry weight (g) of different sorghum cultivars as affected by gamma irradiations: Doses, cultivars and doses $\times$ cultivars interaction produced highly significant $(\mathrm{p}<0.05 \%)$ effects on dry weight of sorghum cultivars (Table 1).

The applied gamma irradiation doses brought a significant decrease in dry weight compared to zero treatment (Table 6). The doses of $15 \mathrm{krad}$ and $25 \mathrm{krad}$ gamma rays induced non-significant changes in dry weight. In the same way, response of sorghum to $20 \mathrm{krad}$ and $30 \mathrm{krad}$ gamma rays were statistically same for subjected parameter. The cultivars varied significantly for dry weight confirming inter-cultivar variations (Table 6; Fig. 5). The effect of doses $x$ cultivars interaction on dry weight of sorghum was highly significant. The performance of selected genotypes for dry weight was very random under different gamma irradiation doses
The study indicated that gamma irradiation can reduce the dry matter of sorghum (Fig. 2). This decrease was due to genetic changes in plants from gamma irradiation which can affect enzyme synthesis in plants. The mutations resulted in decrease of enzyme activity ( $\mathrm{Li}$ et al., 2015), thereby reducing the dry matter (Scully et al., 2016; Delastra et al., 2021). Lehninger (1982) confirmed the fact that mutations can inhibit production and physiology of several enzymes thereby affecting various pathways responsible for synthesis of various organic substances resulting in low dry biomass. Previous reports regarding seedling dry weight (Borzouei et al., 2010; Jagajanantham et al., 2012) under gamma irradiation are in complete accordance to our study, thus confirming the present finding 


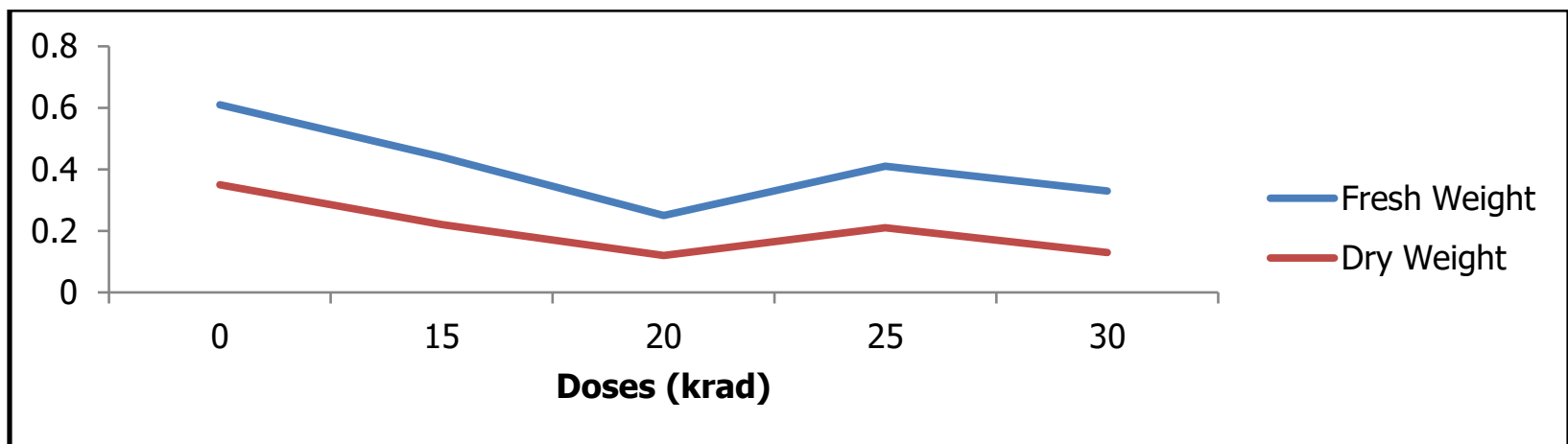

Fig 2. Effect of gamma irradiation on fresh and dry weight (gm) of Sorghum vulagare $\mathrm{L}$.

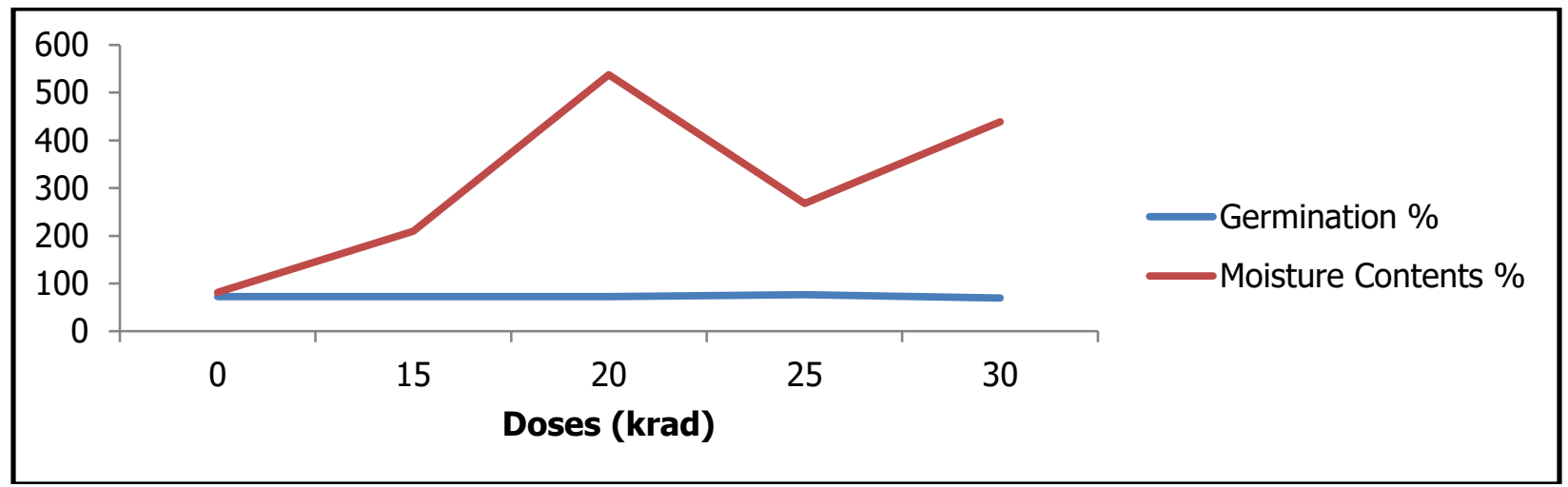

Fig 3. Effect of gamma irradiation on germination (\%) and moisture contents (\%) of Sorghum vulgare L.

Table 6. Effect of gamma irradiation (krad) on dry weight (g) of Sorghum vulgare L. cultivars.

\begin{tabular}{|c|c|c|c|c|c|}
\hline & Asian & Indian & Mycho & Summer graze & Doses means \\
\hline Control & $0.26^{\text {cde }}$ & $0.11^{\mathbf{f}-\mathbf{i}}$ & $0.58^{\mathrm{a}}$ & $0.43^{\mathbf{b}}$ & $0.35^{\mathrm{a}}$ \\
\hline 15 & $0.31^{\mathrm{bcd}}$ & $0.04^{\mathrm{hi}}$ & $0.35^{\text {bc }}$ & $0.17^{\mathrm{d}-\mathrm{h}}$ & $0.22^{b}$ \\
\hline 20 & $0.18^{\mathbf{d}-\mathbf{h}}$ & $0.19^{\mathrm{d}-\mathrm{g}}$ & $0.06^{\text {ghi }}$ & $0.06^{\text {ghi }}$ & $0.12^{\mathrm{c}}$ \\
\hline 25 & $0.16^{\mathrm{e}-\mathrm{i}}$ & $0.19^{\mathrm{d}-\mathrm{g}}$ & $0.44^{\mathrm{ab}}$ & $0.03^{\mathrm{i}}$ & $0.21^{\mathbf{b}}$ \\
\hline 30 & $0.24^{\mathrm{c}-\mathrm{f}}$ & $0.07^{\mathrm{ghi}}$ & $0.18^{\mathrm{d}-\mathrm{g}}$ & $0.02^{\mathrm{i}}$ & $0.13^{\mathrm{c}}$ \\
\hline Cultivars means & $0.23^{\mathbf{b}}$ & $0.12^{\mathrm{c}}$ & $0.32^{\mathrm{a}}$ & $0.15^{\mathrm{c}}$ & \\
\hline
\end{tabular}

Lsd value at $0.05 \%$ level of significance for Doses $=0.07181$, Cultivars $=0.06423$ and Doses $\mathrm{x}$ Cultivars interaction $=$ 0.1436 . Values bearing similar letters in rows and columns are statistically non-significant at $0.05 \%$ level of significance.

Effects of gamma rays on moisture contents $(\%)$ of sorghum cultivars: Doses, cultivars and doses $\times$ cultivars interaction instigated highly significant changes in moisture contents (\%) of sorghum (Table 1). Unlike other parameters, gamma irradiation brought significant increase in moisture content (\%) of sorghum as compared to control treatment (Table 7). The highest moisture content $(537.62 \%)$ value was recorded under a dose of 20 krad followed by 30,25 and $15 \mathrm{krad}$ of gamma irradiation as 439.04, 267.58 and $209.76 \%$. The cultivars Asian and Mycho showed non-significant moisture content values. Similarly, moisture content values recorded from cultivars Indian and Summer graze were non-significant variations. The doses $\times$ cultivars interaction enhanced moisture contents of cultivars Mycho and Summer graze under different irradiation doses (Fig. 3). On the other hand, the effect of doses $\times$ cultivars interaction on moisture contents of cultivars Asian and Indian were inconsistent and random. The exposure of a biological system to ionizing radiation activates a number of physical and chemical steps between the initial absorption of energy and the final biological injury. One of the most important targets is the water molecule. The ionized water molecule and the radicals are produced due to the primary reactions of excitation and ionization. These radicals can damage or modify important components of plant cells and affect certain physiological and biochemical processes that might be vital for organism survival (Marcu et al., 2013). The given logic is seemed to be operating in the present case also. Ionization brought scarcity of water thereby compelled sorghum to absorb more water (Fig. 3). Among the cultivars, Indian with significantly higher and Asian with the lower moisture contents was the prominent cultivars (Fig. 6). The stimulation of moisture contents 
due to gamma irradiation in the present study is in contrast to the reported negative effects of gamma irradiation on moisture contents of Pisum sativum (Navena, 2002) and Lathyrus sativus (Tripathi \& Kumar, 2010). Unlike present findings, negative effects of gamma irradiation on the moisture contents of pea (Tripathi \& Kumar, 2010) have been reported which contradicts the present findings.

Table 7. Effect of gamma irradiation (krad) on moisture contents (\%) of four Sorghum vulgare L. cultivars.

\begin{tabular}{|l|l|l|l|l|l|}
\hline Doses (krad) & Asian & Indian & Mycho & Summer graze & Doses means \\
\hline Control & $104.11^{\text {de }}$ & $127.14^{\text {de }}$ & $40.21^{\mathbf{e}}$ & $54.06^{\mathbf{e}}$ & $81.38^{\mathbf{c}}$ \\
\hline 15 & $91.56^{\text {de }}$ & $287.04^{\text {cde }}$ & $334.02^{\text {cde }}$ & $126.40^{\text {de }}$ & $209.76^{\text {bc }}$ \\
\hline 20 & $113.22^{\text {de }}$ & $1135.12^{\mathbf{a}}$ & $415.00^{\mathbf{b}-\mathbf{e}}$ & $487.12^{\text {bed }}$ & $537.62^{\mathbf{a}}$ \\
\hline 25 & $148.74^{\text {de }}$ & $119.38^{\text {de }}$ & $61.53^{\mathbf{e}}$ & $740.66^{\text {ab }}$ & $267.58^{\mathbf{b c}}$ \\
\hline 30 & $145.62^{\text {de }}$ & $666.97^{\text {bc }}$ & $166.92^{\text {de }}$ & $776.66^{\text {ab }}$ & $439.04^{\text {ab }}$ \\
\hline Cultivars means & $120.65^{\mathbf{b}}$ & $467.13^{\mathbf{a}}$ & $203.54^{\mathbf{b}}$ & $436.98^{\mathbf{a}}$ & \\
\hline
\end{tabular}

Lsd value at $0.05 \%$ level of significance for Doses $=202.2$, Cultivars $=180.8$ and Doses x Cultivars interaction $=404.3$.

Values bearing similar letters in rows and columns are statistically non-significant at $0.05 \%$ level of significance.

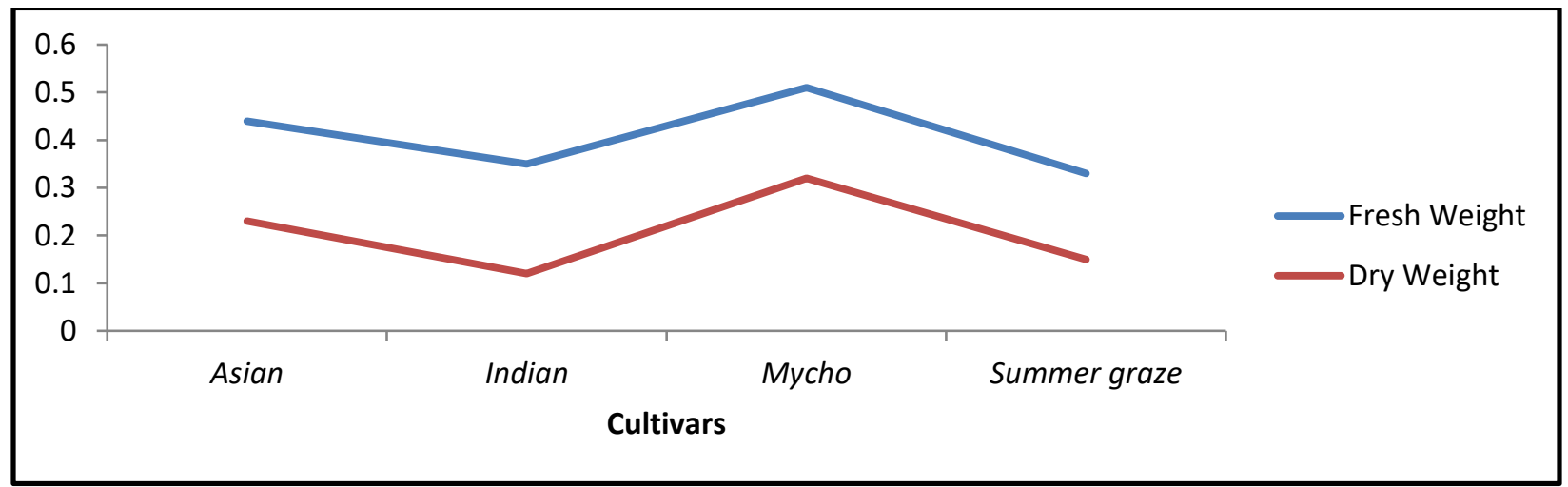

Fig 5. The varietal differences among selected Sorghum vulgare L. cultivars in terms of fresh and dry weight (g).

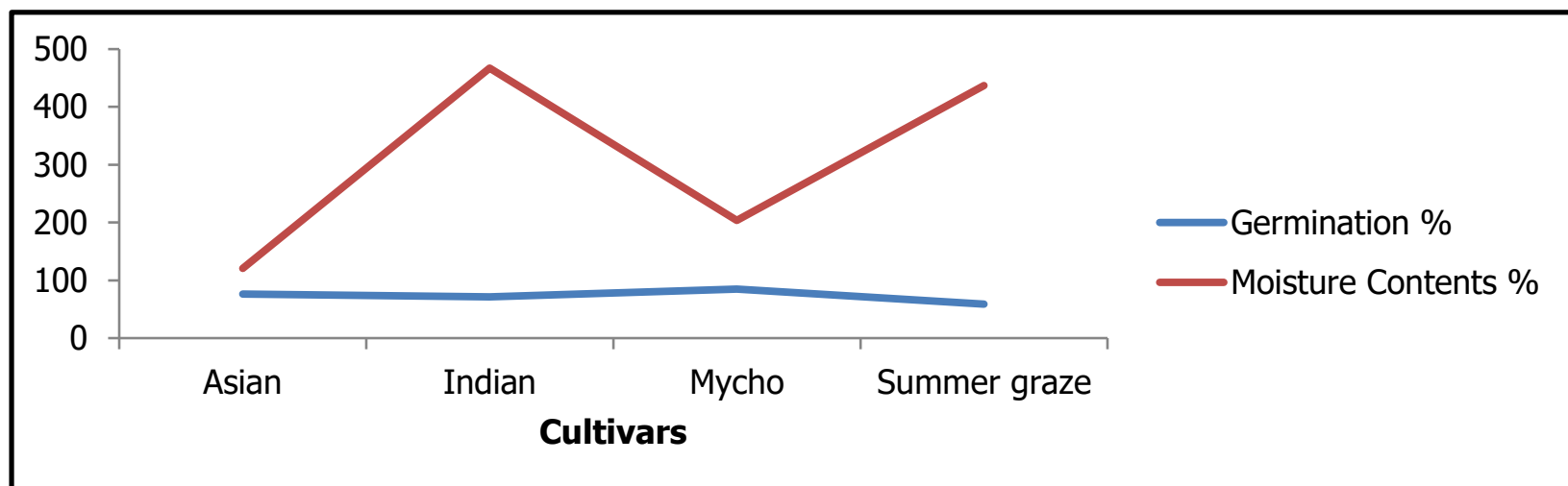

Fig 6. The varietal differences among selected Sorghum vulgare $\mathrm{L}$. cultivars in terms of germination and moisture contents $(\%)$.

\section{Conclusion}

From the studied facts, it is clearly visible that gamma irradiation is stimulatory for moisture contents of Sorghum vulgare L. But at the same time, gamma rays failed to enhance seedling growth and biomass yield of sorghum cultivars over control treatment. Germination showed non-significant responses under gamma radiation treatments. Among the cultivars, Mycho with maximum seedling growth and biomass was a prominent cultivar. The cultivar Indian showed its superiority only in one parameter (moisture contents (\%)) over the rest of the cultivars. The doses $\times$ cultivars interaction affected all the studied attributes significantly except plumule growth 
revealing dose dependent response of cultivars under gamma rays treatment.

\section{References}

Ahloowalia, B.S., Maluszynski, M. \& Nichterlein, K. (2004). Global impact of mutation-derived varieties. Euphytica, 135: 187-204.

Akshatha \& Chandrashekar, K.R. (2013). Effect of gamma irradiation on germination growth and biochemical parameters of Pterocarpus santalinus, an endangered species of Eastern Ghats. Europe Journal of Experimental Biology, 3: 266-270.

Akshatha, Chandrashekar, K.R., Somashekarappa, H.M. \& Souframanien, J. (2013). Effect of gamma irradiation on germination, growth, and biochemical parameters of Terminalia arjuna Roxb. Radiation Protection and Environment, 36(1): 38-44.

Al-Rumaih, M.M. \& Al-Rumaih, M.M. (2008). Influence of ionizing radiation on antioxidant enzymes in three species of Trigonella. Am. J. Environ. Sci., 4: 151156

Ambavane, A. R., Sawardekar, S. V., Sawantdesai, S. A., \& Gokhale, N. B. (2015). Studies on mutagenic effectiveness and efficiency of gamma rays and its effect on quantitative traits in finger millet (Eleusine coracana L. Gaertn). Journal of Radiation Research and Applied Sciences, 8(1), 120-125.

Borzouei, A., Kafi, M., Khazaei, H., Naseriyan, B. \& Majdabadi, A. (2010). Effects of gamma radiation on germination and physiological aspects of wheat (Triticum aestivum L.) seedlings. Pak. J. Bot., 42(4): 2281-2290.

Chaudhuri, S.K. (2002). A simple and reliable method to detect gamma-irradiated lentil (Lens culinaris Medik.) seeds by germination efficiency and seedling growth test. Radiat. Phys. Chem., 64: 131136.

Cheema, A.A. \& Atta, B.M. (2003). Radiosensitivity studies in basmati rice. Pak. J. Bot., 35(2): 197-207.

Delastra, N.M., Astuti, A., Suwignyo, B., Muhlisin \& Umami, N. (2021). Gamma radiation effect on growth, production and lignin content of Sorghum sudanense at different harvest ages. Buletin Peternakan, 45(3): 183-188.

Dubey, A.K., Yadav, J. R. \& Singh, B. (2007). "Studies on induced mutations by gamma irradiation in okra (Abelmoschus esculentus (L.) Monch," 7(1/2): 4648.

El-Sherif, F., Khattab, S., Ghoname, E., Salem, N. \& Radwan, K. (2011). Effect of gamma irradiation on enhancement of some economic traits and molecular changes in Hibiscus Sabdariffa L. Life Science Journal, 8(3): 220-229.

Hanafy, S.R. \& Akladious, A.S. (2018). Physiological and molecular studies on the effect of gamma radiation in fenugreek (Trigonella foenum-graecum L.) plants. Journal of Genetic Engineering and Biotechnology, 16(2): 683-692.

Hegazi, A. Z. \& Hamideldin, N. (2010). "The effect of gamma irradiation on enhancement of growth and seed yield of okra [Abelmoschus esculentus (L.) Monech] and associated molecular changes," Journal of Horticulture and Forestry, 2(3): 038-051.

Hussain, F. (1989). Field and laboratory manual of plant ecology. N.A.H.E., University grand commission, Islam Abad.

Irfaq, M. \& Nawab, K. (2001). Effect of gamma irradiation on some morphological characteristics on three wheat (Triticum aestivum L.) cultivars. J. Biol. Sci., 1: 935-937.

Jagajanantham, N., Dhanavel, D., Pavadai, P. \& Chidambaram, A.A. (2012). Growth and yield parameters using gamma rays in bhendi (Abelmoschus esculentus (L.) Moench) var. arka anamika. International Journal of Research in Plant Science, 2(4): 56-58.

Kobori, N. N., Mastrangelo, T., Cicero, S. M., Cassieri, P., Moraes, M. H. D., \& Walder, J. M. M. (2010). Effects of gamma irradiation on physiological and phytosanitary qualities of Brazilian castor bean seeds, Ricinus communis (cv. IAC Guarani). Research Journal of Seed Science, 3(2), 70-81.

Khan, M.R., Qureshi, A.S., Hussain, S.A. \& Ibrahim, M. (2005). Genetic variability induced by gamma irradiation and its modulation with gibberellic acid in M2 generation of chickpea (Cicer arietinum L.). Pakistan Journal of Botany, 37(2): 285-292.

Kiong, A.L.P., Lai, A.G., Hussein, S. \& Harun, A.R. (2008). Physiological responses of Orthosiphon stamineus plantlets to gamma irradiation. AmEurasian. J. Sustain. Agric., 2: 135-149.

Kumar, A. \& Mishra, M.N. (2004). Effect of gamma-rays, EMS and NMU on germination, seedling vigour, pollen viability and plant survival in M1and M2 generation of okra (Abelmoschus esculentus (L.) Moench). Advances in Plant Science, 17(1): 295297.

Latif, H.H., Abdalla, M.A. \& Farag, S.A. (2011). Radiostimulation of phytohormons and bioactive components of coriander seedlings. Turk. J. Biochem., 36(3): 230-236.

Larik, A.S., Memon. S. \& Soomro, Z.A. 2009. Radiation induced polygenic mutations in Sorghum bicolor L. Journal of Agricultural Research, 47: 11-9.

Lehninger, A.L. (1982). Basics of Biochemistry. Erlangga, Jakarta.

Li, Y., Mao, P., Zhang, W., Wang, X., You, Y., Zhao, H., Zhai, L. \& Liu, G. (2015). Dynamic expression of the nutritive values in forage sorghum populations associated with white, green and brown midrid genotypes. Field Crops Research, 184: 112-122. 
Maamoun, M.K.M., El-Mahrouk, M.E., Dewir, Y.H. \& Omran, S.A. (2014). Effect of radiation and chemical mutagens on seeds germination of black cumin (Nigella sativa L). Journal of Agricultural Technology, 10(5): 1183-1199.

Marcu, D., Damian, G., Cosma, C. \& Cristea, V. (2013). Gamma radiation effects on seed germination, growth and pigment content and ESR study of induced free radicals in maize (Zea mays). $\mathrm{J}$ Biol Phys., 39: 625-634.

Moghaddam, S.S., Jaafar, H., Ibrahim, R., Rahmat, A., Aziz, M.A. \& Philip, E. (2011). Effects of acute gamma irradiation on physiological traits and flavonoid accumulation of Centella asiatica. Molecules, 16: 4994-5007.

Moussa, H. R. (2011). Low dose of gamma irradiation enhanced drought tolerance in soybean. Agronomica Hungarica, 59, 1-12.

Nevena, S. (2002). Physiological effects of the synthetic growth regulator thidiazurol (drop) on gammairradiated stress in peas plants (Pisum sativum). Journal of Central European Agriculture, 3(4): 291300.

Peykarestan, B. \& M. Seify. (2012). Uv irradiation effects on seed germination and growth, protein contents, peroxidase and protease activity in redbean. International Research Journal of Applied and Basic Sciences, 3(1): 92-102.

Preuss, S.B. \& Britt, A.B. (2003). A DNA-damageinduced cell cycle checkpoint in Arabidopsis. Genetics, 164: 323-334.

Santosa, E., Pramono, S., Mine, Y., \& Sugiyama, N. (2014). Gamma irradiation on growth and development of Amorphophallus muelleri Blume. Journal Agronomi Indonesia, 42(2), 118- 123.

Sarduie, N.S., Sharifi, S.G.R. \& Torabi, S.M.H. (2010). Assessment of dissimilar gamma irradiations on barley (Hordeum vulgare spp.). J. Plant Breed Crop Sci., 4: 059-063.

Scully, E.D., Gries, T., Funnell-Harris, D.L., Xin, Z., Kovacs, F.A., Vermerris, W. \& Sattler, S.E. (2016). Characterization of novel brown midrib 6 mutations affecting lignin biosynthesis in sorghum. J. Integral Plant Biol., 58: 136-49.

Selvaraju, P. \& Raja, K. (2001). Effect of gamma irradiation of seeds on germination of different tree species. In proceedings of IUFRO joint symposium on tree seed technology, physiology and tropical silviculture, pp: 141-142.
Shah, T.M., Mirza, J.I., Haq, M.A. \& Atta, B.M. (2008). Radio sensitivity of various chickpea genotypes in M1 generation I-Laboratory studies. Pak. J. Bot., 40: 649-665.

Sherif, F. E., Khattab, S., Ghoname, E., Salem, N., \& Radwan, K. (2011). Effect of gamma irradiation on enhancement of some economic traits and molecular changes in Hibiscus sabdariffa L. Life Science Journal, 8, 220- 229.

Steel, R.G.D. \& Torrie, J.H. (1984). Principles and procedures of statistics. A biometrical approach. 2ndEd. McGraw Hill Book, Co. Inc.New York.

Tabasum, A., Cheema, A.A., Hameed, A., Rashid, M. \& Ashraf, M. (2011). Radio sensitivity of rice genotypes to gamma radiations based on seedling traits and physiological indices. Pak. J. Bot., 43(2): 1211-1222.

Tarroum, M. Khan, S. \& Al-Qurainy, F. (2011). Evaluation of drought tolerance of $\gamma$-irradiated mutants of Hordeum vulgare. Journal of Medicinal Plants, 5(14): 2969-2977.

Thapa, C.B. (2004). Effect of acute exposure of gamma rays on seed germination and seedling growth of Pinus kesiya Gord and P. wallichiana A.B. Jacks. Our Nature, 2: 13-17.

Tripathi, R.S.N. \& Kumar, G. (2010). Comparative effect of ageing and gamma irradiation on the somatic cells of Lathyrus sativus L. J. Cent. Eur. Agric., 11(14): 437-442.

Ullah, H. 2014. (2014). Estimation of induced variability of yield contributing traits in M1gamma irradiated germplasm of Okra (Abulmoschus Esculentus L.)," South Asian Journal of Life Sciences, 2(1): 4-7.

Vandenhodt, H., Nathalie, V., May, V.H., Jean, W. \& Nele, H. (2010). Life-cycle chronic gamma exposure of Arabidopsis thaliana induces growth effects but no discernable effects on oxidative stress pathways. Plant Physiology and Biochemistry, 48(9): 778-786.

Wanga, A.M., Shimelis, H., Horn, N.L. \& Sarsu, F. (2020). The Effect of single and combined use of gamma radiation and ethylmethane sulfonate on early growth parameters in sorghum. Plants, 9(827): $1-15$.

Zanzibar, M. \& Sudrajat, J.D. (2016). Effect of gamma irradiation on seed germination, storage, and seedling growth of Magnolia champaca L. Indonesian Journal of Forestry Research, 3(2): 95106.

Publisher's note: JOARPS remains neutral with regard to jurisdictional claims in published maps and institutional affiliations.

This is an open access article distributed under the terms of the Creative Commons Attribution License (CC BY 4.0), which permits unrestricted use, distribution, and reproduction in any medium, provided the original author and source are credited. To

view a copy of this license, visit http://creativecommons.org/licenses/by/4.0/. 